\title{
Between phatic communion and coping tactic. Casamançais multilingual practices
}

\author{
Tilmann Heil \\ University of Konstanz
}

\begin{abstract}
This paper enquires into the role of multilingual practices in conviviality in shared, socially and culturally mixed localities. I ask how Casamançais use diverse repertoires to get by in everyday life in both Casamance, Senegal and Catalonia, Spain. The concept of conviviality stresses fragile, dynamic processes characteristic of everyday ways of living together with maintained difference. I argue that minimal, but diversified language practices, which compose linguistically diverse repertoires, are central in facilitating conviviality among local residents. Minimal interactions and 'small talk', or phatic communion, cushion potentially conflictual socio-cultural differences and inequalities. Firstly, I will evaluate discourses on multilingual practices of Casamançais in both contexts. Second, I will critically explore the reasons for and quality of the widespread use of diverse repertoires. I conclude that multilingual practices facilitate phatic communion sometimes playfully and sometimes as part of coping strategies in situations in which structural forces determine which choices will be more successful than others. The process of conviviality spans both these aspects describing everdynamic and ever-fragile ways of living with difference.
\end{abstract}

Keywords: everyday; conviviality; phatic communion; tactics; inequality; Casamance; Catalonia; multilingualism; polylanguaging

\section{INTRODUCTION}

I n shared, socially and culturally mixed localities truncated multilingual practices are a central element of conviviality, a mode of minimal sociality among people who maintain differences. ${ }^{1}$ In both Catalonia and Casamance, where I conducted ethnographic fieldwork among Casamançais migrants and their families and friends, diverse linguistic repertoires are used to get by in everyday life. To an extent, this reflected the linguistically diverse local population. ${ }^{2}$ Catalonia's everyday bilingualism of Catalan and Castilian has seen further diversification due to immigration and Catalan is politically promoted as the shared lingua franca; in Casamance, various linguistic preferences persist alongside local, regional, and national linguae francae. In both localities, inhabitants use diverse linguistic repertoires to get by in everyday life. I will argue that truncated, but diversified language practices, which compose linguistically diverse repertoires, are central in facilitating conviviality among local residents. Minimal interactions and 'small talk' cushion potentially conflictual cultural differences and social stratification. 
Well aware that minimal interactions change over time and according to wider social contexts (cf. Heil 2013), here I discuss the significance of 'knowing just enough', i.e. developing a truncated multilingual register needed to sustain minimal interactions. I ask how such truncated multilingualism facilitates conviviality by way of 'phatic communion' (cf. Malinowski [1923] 1994), which I define as a sequence of situations in which people communicate using minimal, mutually intelligible semiotic resources. Truncated multilingualism refers to repertoires which vary in degrees of diversity but result from 'creatively appropriat[ing] the voices of others across language boundaries, while [potentially only] possessing a very limited knowledge of the languages being appropriated' (Blommaert, Collins, and Slembrouck 2005: 199). I use this interchangeably with polylanguaging which describes 'the use of features associated with different "languages" even when speakers only know few features associated with (some of) these "languages" (Jørgensen 2011: 33). In the cases discussed in this paper, some interlocutors exhibited quite sophisticated linguistic knowledge, yet they often had proven to be specialists in 'knowing just enough' of particular languages and further cultural practices which they had 'learned in passing'. I am particularly interested in the moments of phatic communion as a form of ritualised interaction, which in (super)diverse contexts requires both truncated multilingualism and cultural translation. Additionally, I question which social differentiations are related to diverse linguistic repertoires and how hierarchies and power discrepancies are negotiated in phatic communion and thus, conviviality. I will therefore account for both the language ideologies and the use of (conflicting) linguae francae in various social situations.

My aim is to engage with the tensions between a playful practice and attitude, and people coping with situations in which structural forces determine which (linguistic) choices are more successful than others. I will explore this dialectic relationship via ethnographic case studies of a Jola, a Mandinka, and a Fula, who only to varying degrees perceive multilingualism as something positive and/or necessary. I will show when the logic of economic interactions obliges them to use various, dominant repertoires beyond their individual linguistic aspirations. Next, I will give some crucial empirical background paying particular attention to the Catalan language policy and the cosmopolitan selfrepresentation and multilingual practices in Casamance.

\section{FRAMING ENCOUNTERS WITH DIFFERENGE}

Although there were common features in the migration trajectories of the mainly male Casamançais I worked with in Catalonia, the cases varied in terms of migration trajectory, the economic means available to them, methods of entry, and living situation upon arrival. The cases of my interlocutors also differed according to places of origin, rural or urban place of residence, ethnic and religious background, formal education, and age. As one important consequence of this diversity of life trajectories, Casamançais over the years had been exposed to variously configured linguistic landscapes. Accounting for this complexity where necessary, both regional contexts nevertheless possess some distinctive features to which my interlocutors referred and which provide frameworks to their multilingual practices and their interpretation. ${ }^{3}$

Both Casamance and Catalonia show diverse linguistic configurations in which I observed a two-sided process. Firstly, diverse linguistic repertoires are commonplace to 
local residents due to complex histories of migration and longstanding ethnic and linguistic plurality. Secondly, this situation is complemented by the role of various languages which assume the role of the regional or situational lingua franca (cf. Juillard 1991; Dreyfus and Juillard 2005; Juillard 2005; Pujolar 2009; Gal 2013; Pujolar and Gonzàlez 2013; Woolard and Frekko 2013). The regional perspective is conducive to the present endeavour since it helps shifting our focus away from a focus on national languages and local mother tongues (cf. Heil 2012). It avoids methodological nationalism as well as an ethnic lens (Wimmer and Glick Schiller 2002; Wimmer and Glick Schiller 2003; Glick Schiller, Çağlar, and Guldbrandsen 2006). Taking subnational regions as an entry point, further categories, such as the national, ethnic, and social ones, continue to play out alongside each other; I will consider them in the following section.

\section{Diversifying Catalonia}

Catalonia is an autonomous region in the northeast of Spain. Not least because of the distinctive language and culture of Catalonia, various political movements and regional institutions have claimed its distinctiveness and relative autonomy from the Castilian-dominated Spanish nation state. After the subaltern endurance of Catalan during the Franco period (May 2012: 257), today Catalan ought to play the role of the 'common public language' (Generalitat de Catalunya 2009: 69), or, put simply, the lingua franca embedded in a policy of active multilingualism. Apart from the Franco legacies, Castilian influences in Catalonia derive from the large internal labour migration from the south of Spain to the north since the 1950s (Castells 2009: 51). They settled in the suburbs of Barcelona and the surrounding industrial towns, where I conducted fieldwork. A further layer of complexity consists of the rapid and significant immigration of international and cheap labour since the early 2000s, which in 2010 locally accounted for 17.5 per cent of the population (Instituto Nacional de Estadística 2011). This immigration is often concentrated in the neighbourhoods built by the southern Spanish arrivals at the periphery of the old Catalan city centres. Currently, this share of the population comes from over 120 different countries of origin (Instituto Nacional de Estadística 2011) and speaks 250 different mother tongues (Generalitat de Catalunya 2009: 69). Independent of their skill level, most international immigrants in the 2000s, certainly those from sub-Saharan Africa, worked in agriculture, factories, construction, the service industries or the informal sector (Díez Nicolás 2002: 266).

Mataró, a medium sized, industrial town some 50 kilometres away from Barcelona, was one of my fieldwork sites and confirms the general picture. In the neighbourhoods at the periphery where I worked, around 50 per cent of the population is born outside Catalonia, all of whom exhibit distinctive, and often multiple diverse linguistic repertoires (Ajuntament de Mataró 2010). Around half of them speak Castilian, often of a Southern Spanish variety. The remaining are international immigrants from other parts of the world and continue to maintain their respective linguistic repertoires.

In such a situation of diversification, the Catalan migration and language policies become particularly apparent. In the renewed Statute of Autonomy in 2006 (Generalitat de Catalunya 2006), which can be regarded as one of the hallmarks of the Catalan independence ambitions, Catalonia emerges as a nation due to its culture and language. It stylises the Catalan culture as mixed and cosmopolitan, facilitating the inclusion of foreigners. 'Un pacte per 
viure junts i juntes. Pacte Nacional per a la

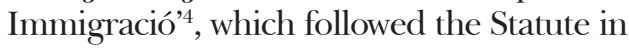
2009, more generally formulates a regional policy on migration and integration and applies some elements of immigration management and control so far dealt with on the state level. Consequently, in 2010 Catalonia was granted the right to issue its own residency and work permits.

The promotion of Catalan language continues in both this National Agreement and its practical application, the Citizenship and Immigration Plan, now also concerning immigrant reception and as a means of bridging the practice of everybody's distinct mother tongue (Generalitat de Catalunya 2009: 69; Generalitat de Catalunya 2010b: 68). The stated aim of the Citizen and Immigration Plan is '... to foster knowledge of Catalan among the entire population of Catalonia, especially among foreigners, and also extend the use of Catalan in all community and social relationship environments.' (Generalitat de Catalunya 2010a: 68).

Eight million Euros have been earmarked for 'Catalan language normalisation' compared to just slightly over 100 thousand Euros for language of origin classes (Generalitat de Catalunya 2010a: 146-48). The imbalance could not be expressed more strongly. In a first step, these policies had mitigated the bilateral political opposition of Castilian and Catalan by embedding it in the practised multilingualism in Catalonia. Yet, as a second step, no doubt remained that Catalan profited as the only lingua franca.

\section{Casamançais linguistic diversity}

In contrast, Casamance is a region of longstanding diversity in the south of Senegal. The national census of 2002 gives 19 different ethnic groups, leaving some to the category of 'other'. Focusing only on the Lower and Middle Casamance where I did fieldwork, those administrative departments with urban agglomerations, Ziguinchor and Sédhiou are very heterogeneous (Agence Nationale de la Statistique et de la Démographie 2008, 2009). Most of the ethnic groups categorised in the census speak recognised national languages. In 1972, Senegal's first president, Léopold Sédar Senghor had officially granted six languages equal status as national languages of Senegal, in contrast to French as the official one. He had envisioned this configuration as a way to foreclose ethnic group-based conflict guaranteeing equal recognition. In 2001, President Wade expanded the 'national' status to all codified local languages which raised the number to currently 24 languages listed as national ones (Diallo 2010).

While many of the linguistic and cultural diversity arguments could be made for Senegal as a whole, Casamançais often claim their home region to be different from the rest of Senegal for its more comprehensive ethnic, linguistic, and religious diversity. The Casamançais distinctiveness was dressed up as cosmopolitan in contrast to the Wolofdominated north. While the reasons for the Casamançais independence movement are complex and multiple (e.g. Lambert 1998; Foucher 2003; de Jong and Gasser 2005; Evans 2005; Marut 2010; Foucher 2011), the cultural specificity of Casamance frequently came to stand next to the more important developmental gridlock and the political marginalisation of the region (Foucher 2002).

While for political purposes the Northerners and Wolof remain the quintessential other of the Casamançais, the Wolof language increasingly plays a role in Casamance as a language of commerce and among youth (Dreyfus and Juillard 2005). According to the 2002 census, in Ziguinchor around 15 per cent speak Wolof as their first language and 53 
per cent as their second, which confirms it as an important, widely spoken language (Agence Nationale de la Statistique et de la Démographie 2008, 2009). However, the census gives no information on further languages spoken, which would be crucial to grasp language dynamics in Casamance. Thus, the picture is already very different in Sédhiou, the second regional capital. 45 per cent name Mandinka as their first language and another 52 per cent as their second one. In Middle Casamance, Mandinka clearly remains the lingua franca. Insights from peripheral markets in Ziguinchor also shows that they mainly operate in local languages, but interactions are often multilingual (Dreyfus and Juillard 2005). In the centre of Ziguinchor and at the main market, multilingual interactions are even more frequent accounting for up to 70 per cent of all interactions. Only in the centre is Wolof used in over 70 per cent of all interactions (ibid.). These aggregate findings already emphasise the need to closely study the local contexts to understand multilingual practices and their representation. The multilingual Ziguinchor configuration sets the context for the linguistic practices of Augustin Sambou ${ }^{5}$, which I discuss next.

\section{BETWEEN A ROCK AND A CONVIVIAL PLACE}

From the outset, Casamançais were exposed to multiple local languages and often had diversified, if truncated multilingual repertoires. To better comprehend the linguistic dynamics in Casamance, I first turn to Augustin Sambou's language practices before introducing the lives of two Casamançais migrants in Catalonia. In contexts of obvious linguistic diversity, I enquire what the reasons are for situationally choosing a specific language or getting on with mixed linguistic practices. How do people relate to the everyday occurrence of polylanguaging? How do they judge multilingual practices? I will arrive at answers to these questions by way of focusing on the various multilingual practices and social processes, which the three distinct cases offer.

\section{Augustin Sambou}

In the local context of Casamance, one does not need to migrate far, if at all, to develop a very varied linguistic repertoire. Augustin came to Casamance in the 1970s as a refugee from Guinea Bissau. He had finished high school in Ziguinchor, had become a primary school teacher, and prepared for an exam for a higher administrative position. One of my close confidants, Augustin had a wide range of linguistic registers from which to choose. He was Jola, the largest ethnic group in Lower Casamance; however, people could tell his dialect was Bissau Guinean. He had only spent a short time in Dakar and, when we met, mainly commuted between various villages in the Casamance-Bissau Guinean borderlands. Following a general trend, he mainly used Wolof in everyday encounters with people of his age. With his more distant relatives from Guinea Bissau, he spoke Creole, with his family members his home dialect of Jola, and with his landlord he spoke Jola Fogny, the most widely used variety. He also handled encounters in Mandinka and some aspects of conversations in Fula. With his colleagues, he conversed in French, while with me he sometimes coquetted in English. Finally, he also understood Portuguese.

Mirroring Augustin's linguistic repertoire, the peripheral neighbourhoods of Ziguinchor were perceived as a similarly diversified linguistic landscape. Despite 
the increasing importance of Wolof, people did not perceive a single language to dominate public interactions and showed an immense linguistic flexibility. People disagreed over situationally dominant linguae francae and the distinctions both among local inhabitants' ethnic origins and linguistic practices were vague, shifting, and constantly evaded efforts to generalise. Sometimes, people spoke of specific ethnic groups or they mentioned which languages were mostly spoken, at other times people just mentioned the great diversity among the inhabitants.

Living in spaces in which their mother tongues were often not the dominant ones, many Casamançais of various ethnic and linguistic backgrounds tended to portray their multilingual practice as a competence and expression of their cosmopolitan attitudes (cf. Heil 2012). This also emerged from the playful, skilful, and easy-going use of diverse repertoires by which Casamançais creatively engaged with the given situation and exchanged nothing more than non-propositional language. At its basis, I witnessed the Casamançais discourses on multilingual practices in both Casamance and Catalonia. In being particularly apt, Augustin embodied both the ideal-typical competence and the aspired cosmopolitan attitude of many Casamançais with whom I interacted. While others just staked a claim to speak many languages, Augustin was more differentiated in his assessment of his language repertoire. He knew his qualities and deficiencies well and humbly put his everyday language practices into perspective. He liked to portray it as the normal way of living, which referred to the expectations of good neighbourliness and thus conviviality (Heil 2014a).

On many days, I could accompany Augustin during his everyday business. On the back of his motorbike or walking with him through Ziguinchor neighbourhoods, he linguistically adapted quite aptly to the changing situations. Contrary to his humble reflections, it seemed that he effortlessly faded in and out of situations and the necessary registers to facilitate interaction. The underlying principles of interaction that Augustin and others stated were the respect for those encountered and the wish to receive difference openly. They portrayed their linguistic skills as a chosen and positively connoted aspect of their everyday social relations. Augustin underlined this point by happily translating for me the discussions that were on-going. More importantly, people would even switch to French for substantial parts of the conversation to have me participate. At the same time, they trained my own expending linguistic repertoire in practising those skills I had acquired in local languages.

On the other hand, most of the time nothing particularly surprising seemed to be said in fleeting encounters. The showing of interest in the neighbour's well-being prescribed by cohabitation in Casamance resembled more ritualised practice than real concern for the other's well-being. Many Casamançais read such forms of politeness and recognition as signs of respect, which were needed, as they argued, since this was Africa. Using merely familiar phrases that pleased those encountered exemplifies a practice which Malinowski described in the 1920s as phatic communion:

A mere phrase of politeness, in use as much among savage tribes as in a European drawing room, fulfils a function to which the meaning of its words is almost completely irrelevant. ... There can be no doubt that we have here a new type of linguistic use - phatic communion ... [T]his is in fact achieved by speech, 
and the situation in all such cases is created by the exchange of words, by the specific feelings which form convivial gregariousness, by the give and take of utterances which make up ordinary gossip. (Malinowski [1923] 1994: 9-10, emphasis in the original)

In a situation of linguistic diversity such as in Casamance, Malinowski's focus on spoken interaction needs some qualifications. The literal meaning of words indeed was irrelevant for Casamançais, yet language ideologies prescribed a need to utter them in (one of) the language(s) accepted or preferred in a given social situation. Often, Casamançais addressed the language ideologies playfully maintaining phatic communion. In situations of unequal power relations, however, their multilingualism presented itself as a tactical choice.

When I went with Augustin to inquire at a mechanic if he had repaired and sold Augustin's old motorbike, Augustin's tactic of using his multilingual repertoire and speaking Wolof failed to establish phatic communion and achieve a positive outcome for the negotiation. While he seemed fluent in Wolof speaking to his friends, he audibly struggled to argue his case to the mechanic. Instead of maintaining his playfulness, his sentences broke up into clumsy junks whenever he had to think of the right technical terms which he frequently could not help but replace with French words. In principle this is not remarkable since Urban Wolof incorporates many French words (Juillard 1994; Swigart 2000; McLaughlin 2008) and 'Wolof only works with a little bit of French', as one of my other informants once explained to me. Augustin, however, later admitted that he had struggled to find appropriate Wolof expressions. The mechanic had also noticed this. As a consequence, Augustin had not convincingly used Wolof features since he neither achieved phatic communion with the mechanic nor his pertinent economic objective of quickly selling his bike. Yet, he had felt under pressure to use Wolof since he envisioned the chances of settling a good deal to significantly increase.

All of a sudden, Wolof was no longer a choice but a way of coping with the situational opportunity structures. They need to be understood as multidimensional hierarchisations, which result from the situational significance of various language registers which people activate, as well as from the perceived social statuses of the people present. The mechanic had been in the centre of town where Wolof increasingly prevailed as a means of interacting commercially. Augustin had chosen a central mechanic despite his difficulties to relate to him due to the language barrier. Yet he needed the services that only this mechanic could offer as a rare specialist. While he previously had had good experiences, this time Augustin's tactic failed. In need of money, he assumed a powerless social position which his meagre attempts at Wolof did not cushion. Judging his own linguistic competences, Augustin knew that he could have been more competent in Jola or French than in Wolof since he had not grown up with it nor used it under such circumstances before. However, the mechanic's situationally superior position based in his professional competence and central location in town had let him dictate the terms of interaction. At least, this must have been Augustin's perception of the situationally specific opportunity structures according to which he had acted. As a consequence, Augustin's difficulties to satisfactorily blend in linguistically and his economically weak position had prevented his successful negotiation.

His intended strategic choice of dealing with his own subject position had not resulted in the expected outcome. 
Put differently, his own Casamançais language ideology of multilingualism had been brought to a limit entering an economic field in which rules governed that he did not master to the required level. Augustin failed at using Wolof as a commodity, which it was intended to be in this economic exchange. Language here needs to be understood from the economic angle (Irvine 1989), from which it could appear as either a strategically applied resource or coping tactic.

In addition to their multilingual selfrepresentation, the linguistic flexibility and creativity of Casamançais thus is, in certain situations, a way of dealing with situational power structures in the attempt to make economic ends meet. Truncated multilingualism and the convivial effects of phatic communion thus may become a currency to cope with real socio-economic disparities. Rather than free play, I argue that Casamançais tried to tactically influence this exchange on the outcome of which they were dependent. Such a situation, I will show next, became more frequent in the emigration context.

\section{Aboubacar Diao}

Aboubacar Diao, a Fula in Catalonia, had felt constrained in his choice of language in interactions on the labour market and in everyday life in Catalonia. He had grown up in an ethnically diverse village of the Sédhiou region, where unlike many other villages in Middle Casamance, the predominance of Mandinka was contested, most fiercely by the locally resident Fula. Meeting him in Catalonia, Aboubacar claimed to have already started to forget Mandinka. Instead, he actively only maintained Wolof and Fula from his Senegalese repertoire. In Catalonia, he had first learned Castilian but quickly changed to Catalan. His young Fula wife from the same village of origin, who had recently arrived and given birth to their child, also took Catalan language classes. Contrary to other migrants, they neither shared their house with family or friends, nor had direct African neighbours. The few Fula living close-by, they hardly visited.

While there were some Casamançais immigrants that felt an immediate interest in the Catalan language as an expression of a regional specificity and diversity much like in Casamance, others like Aboubacar had initially set out to learn Spanish since their work trajectories would not be limited to Catalonia alone. Back then, Aboubacar had reasoned that Catalan was of no use in the rest of Spain and Europe. This rational argument ranking languages paralleled a similar practice in Senegal. In general, Fula and Mandinka speakers discredited Wolof since they thought its geographical reach was limited to Senegal and Gambia alone. In contrast, both Mandinka and Fula were languages with a trans-regional or-as some liked to claim-a pan-African reach. Neither Catalan nor Wolof could claim such a significance. Yet, reasons beyond possible onward migrations led to a re-evaluation of specific language ideologies. For example, Aboubacar preferred Wolof to Mandinka due to his direct confrontation with Mandinka in his village of origin. Casamançais entextualise their own situation in the contexts of (competing) language ideologies. Therefore, Aboubacar had started to care for Catalan.

The first day I met Aboubacar and his wife, he had just come back from a Catalan class. Being reluctant to learn Catalan at first, the Diaos had observed three practical reasons for positively engaging and learning Catalan. On the labour market and in public institutions, Catalans would increasingly assume 
Catalan as the lingua franca and not switch to Castilian automatically, thus limiting the access of those not able to speak Catalan. To participate locally and to achieve one's own goals it was necessary to avoid such situations. Second, knowing that someone only understood Castilian, Catalans could speak about him or her in Catalan unnoticed. Since this was potentially dangerous, it needed to be prevented at all costs. Finally, the Diaos noticed that a group of locals would receive someone well if addressed in Catalan. ${ }^{6}$ While this applied to all immigrants, sub-Saharan Africans frequently earned a lot of respect from the Catalans for their high linguistic sensibility. Among them, all three dimensions had been recurrent themes reiterating the importance of Catalan. Those not knowing Catalan risked being excluded and potentially discriminated against. To prevent this, the Diaos regularly attended Catalan classes and did not rely on the vernacular everyone else picked up on the street.

Taking classes in Catalan contrasted with Aboubacar's attitude to Castilian that he only continued to pick up on the streets and at work. The working class street register of Castilian and some minimal knowledge of Catalan would have sufficed for Aboubacar to work in low-skilled employment and maintain phatic interactions as many Casamançais did. Indeed, some Casamançais without formal education sounded like their Andalusian neighbours and work colleagues, and thus succeeded in creating phatic communion and earning their living. Aboubacar, however, aspired to more, he envisioned himself upwardly mobile for which he needed to extend his proficiency in Catalan. Seemingly as a side product of this aspiration, the Diaos had bought into the autonomy narrative of Catalonia with its own culture and language, which for them was a legitimate explanation of the increasing pride of Catalans and their efforts to promote Catalan. Apart from being a sign of respect for regional specificity, plenty of Casamançais furthermore sympathised with the Catalan minority concern similar to that of the Casamançais in Senegal, and the symbolic role of Jola, Mandinka, and other even smaller language groups therein. Quite literally, they compared and translated the cultural dynamics of the two regions, thus making them intelligible.

As the dominant narrative, however, Aboubacar portrayed his efforts to speak and understand Catalan as a tactical choice, which was facilitated by some sympathy for a minority language. He felt a need for Catalan to approach people and to find work; he tactically tried to comply with the requirements set by those who could either grant or deny access to employment and services. In contrast to others who had transplanted some of their linguistic playfulness to Catalonia, his engagement with Catalan showed little of such an attitude. To achieve his own goals, Aboubacar seemingly did the necessary by using the resource of the dominant local lingua franca.

Language ideologies promoting a single lingua franca thus have the potential to challenge truncated multilingualism as the basis of phatic communion. The imposition of regionally dominant or politically favoured linguae francae like Catalan, Mandinka or Wolof puts the relative equality among interacting parties and their linguistic repertoires and registers at risk. This can result in spaces being claimed by some local residents who then intend to impose their language preferences on others. In large shares of the public and economic sphere of Catalonia, Catalans occupied such a position. Nevertheless, most Casamançais 
(seemingly) playfully maintained phatic communion for either normative or tactical reasons, or both.

None of the aspects facilitating phatic communion in a local social field can thus be taken for granted. For many Casamançais, cultural translation and sustaining the local style of address are in general a morally correct tactical choice. ${ }^{7}$ However, normative evaluations of social, cultural, and religious collective and individual aspirations, and of local configurations of language ideologies challenge its feasibility. Some Casamançais struggled with differences in what constituted phatic exchange. For example, rushing social encounters or reducing them was hardly translatable for Casamançais who believed in the importance of making time for encounters as part of Casamançais cohabitation. Additionally, educated Casamançais interacting with working-class Andalusian neighbours found it hard to generously equate their different practices due to the class differences; they were appalled by unpleasant working-class small talk. Yet this emotionally trapped them between their disdain and mockery of their neighbours' repertoires, and their own lack of respect this portrayed.

Indeed, Aboubacar had been struggling to cope with the local forms of creating phatic communion. Despite learning the language, he stated his preference at work and outdoors to interact as little as possible, mainly to avoid trouble. While he would watch and listen, he never commented or joked. To him local ways of joking were frequently insulting rather than funny. Apart from speaking as little as possible, Aboubacar also explained to keep his bodily expressions to a minimum, for example not looking into the eyes of passers-by.

Aboubacar's limited engagement at work and in public, as well as his multilingual choices mirror his constant evaluation of how to most efficiently deal with current conditions. From the outset in Casamance, he had only picked up language repertoires that were useful to know. Thus, he stopped at the level of greeting in Castilian but invested more in Catalan after he had seen possible pitfalls in case he did not. He quickly invested in the latter to access realms of society from which he otherwise found himself excluded. Part of this logic was also, to keep the encounters to a minimum of acknowledging each other's presence and distinctiveness.

Like in Casamance, Aboubacar had used the suitable registers and forms of interaction to the necessary extent. To recognise such locally specific forms of interaction was also part of the process of cultural translation, i.e. the successful translation between multiple systems of meaning, making them intelligible and moving between them. Casamançais expressed their disposition towards such practices through a close observation of local sociality which they compared to their previous social experiences and to the information gained from comigrants in the new place. In contrast to Aboubacar, who tactically reacted to changing circumstances, we will see next how Idrissa Samaté believed in the genuine usefulness of multiple languages and how he mastered the fine-tuning of situational styles and registers with a certain playfulness.

\section{Idrissa Samaté}

Idrissa Samaté, a Mandinka from Sédhiou town, had been politically well connected in a socialist-Marxist party which had ceased to exist leaving various splinter groups behind. As a result, Idrissa felt that his future in Senegal 
had waned and decided to try migration inspired by his foster brother, whom he eventually joined in Spain. He had left his wife and children behind to start the life of a migrant exposed to the vagaries of an uncertain future, which was in contrast to his initially promising outlook in Senegal.

Explaining his linguistic repertoire, he stressed his secure family background and formal education in Senegal at the University of Dakar. His whole family was at least fluent in French, Wolof, and Mandinka. Idrissa himselfwas a recognised language authority for Mandinka, his mother tongue, both in Casamance and Catalonia. The Casamançais advertising his language proficiency often implied more than just language: they meant a profound knowledge of Mandinka cultural practices and their texts. For this reason, Idrissa regularly received visitors on weekends who came from neighbouring towns to attend his gatherings or causeries. Furthermore, they demanded his guidance in rituals at any kind of cultural event that was held in and around his current place of residence.

Idrissa's extensive knowledge of home combined with an active engagement with the Catalan locality. Like many others, Idrissa believed in the centrality of being able to communicate in a new context in which he invested a lot from the start. Although he dedicated most of his time to migrant associations, he had shown an interest in local associations and always participated in associational meetings on the municipality level. When I met him seven years after his arrival in Catalonia, he furthermore had become a relatively well-known and respected figure in the trade unionism of Catalonia.

Working for one of the main trade unions in the field of migrants' rights, he spent his days using the full scope of his linguistic repertoire. In campaigns, he emphasised the importance of interacting with Moroccan and Latin American workers as well as sub-Saharan ones. In the office block, however, his Catalan register proved important. On the corridors and in casual meetings he constantly exchanged the odd question and short commentary with his co-workers. In style he adjusted to the union environment, addressing most people as compañera/o, company $/ a$, or camarada. ${ }^{8}$ Which one of the Castilian or Catalan union forms of address he used remained often unclear since he kept a low voice throughout the day. Speaking softly was one major difference he had previously identified between here and there, referring broadly to Catalonia, Spain, or Europe on the one hand, and Casamance, Senegal, or Africa on the other. Apart from scripted responses, he most of the time earned a recognising smile. By the time I met him, Idrissa had become a widely known person throughout the office block and had secured his social position. While this was partly due to being one of the few migrants working there, his efforts put into knowing enough Catalan and fitting in stylistically had their effect and facilitated phatic communion and everyday conviviality.

To get on in multiple languages had always been helpful to him. Knowing Wolof and French had been useful resources in Senegal and continued to be in Spain. In Catalonia, Idrissa assured me that knowing either some Catalan or Castilian was a mandatory first step to integrate, as he phrased it. However, he himself made use of them both. Catalan was important at the office and in dealing with the municipality, but Castilian was a central means to get by in the neighbourhood. Apart from the many Moroccans and Latin Americans with 
whom Idrissa used español or 'Spanish', it also served with the Anglophone and Lusophone sub-Saharan immigrants. With fellow Africans little or unknown, the geographical scope of Mandinka, Wolof and French was simply too limited to facilitate communication.

Despite knowing the value of linguae francae, in our discussion Idrissa made the case for the general desirability of polylanguaging. He repeatedly stated that it was desirable to learn further languages such as his mother tongue, Mandinka, or Jola. $^{9}$ His support of various co-existing language ideologies demonstrates the multiple allegiances with which multilingualism plays. The lingua franca of a place is crucial, but being able to situationally draw from a wide repertoire certainly had a positive effect on facilitating conviviality. Thus, Idrissa would use 'union-Catalan' at work, 'Spanish' with strangers, Wolof with Senegalese, and Mandinka with the people who knew him and at home. Even Idrissa did not always seek proficiency in the standard register. Especially the proximity of Castilian, Catalan, and French invited creative improvisations, a skill many Casamançais had. Idrissa regularly experienced that this would work since in phatic communion language ideologies were easily satisfied by partial and fragmentary, yet appropriate language practice.

Idrissa embraced multiple languages more than most of my informants. To be as successful as he was in both keeping a high social standing in the migrant community and among co-workers, he had developed an advanced sense of appropriate registers and styles. Whether in the trade union, in migrant associations, in public spaces or at home, Idrissa consciously adjusted to every encounter. Although he had achieved more than most Casamançais and he seemingly enjoyed himself, he occasionally portrayed his life and with it the language choices as a way of coping as an immigrant. Drawing on this migration discourse and alluding to the necessary efforts of the apprenticeship on which he had embarked was just another way of engaging with political dynamics at hand. While Idrissa genuinely believed in the appropriateness of polylanguaging, he also was strategic enough to dress it up as a coping tactic specific to a migrant's life, which was convincing in times of increasingly dominant and exclusivist language ideologies as in the case of Catalan. Idrissa's case thus offers a reading of a generally embracing engagement with polylanguaging for the sake of phatic communion and, in consequence, conviviality; however, it also raises an awareness for the tactical use of polylanguaging within the wider discourse of immigration.

\section{CONCLUSIONS}

In the introduction, I asked to what extent Casamançais polylanguaging is a way of playfully facilitating phatic communion and conviviality, and how far is it a result of a wider coping tactic of people who often hold a comparatively powerless subject position. It is worth remembering that multilingual practices of the same people play out in a number of situations, for example, (seemingly) unintentional everyday encounters in public space, meetings in political contexts, and economic interactions. In this regard, multilingualism is both intended and practised in various ways depending on the overall configurations of the context and the social situation itself. The three examples have shown that it is a process found among people of disparate socioeconomic backgrounds. Depending on all of these factors - the actual situation, the structural context, and the subject 
position of the speaker-multilingual practices facilitate phatic communion sometimes playfully and sometimes as part of coping tactics.

Looking at the regional contexts, Casamance and Catalonia are structured by quite different configurations of language ideologies. While in Casamance multilingual practices were part of the regionally dominant discourse, in Catalonia the Catalan language ideology supported Catalan as the main lingua franca. Catalan dominated in the political sphere and in Catalan work environments. Both Aboubacar and Idrissa alluded to this; yet, their cases also showed that it was often enough to know some Catalan features to achieve conviviality. Moreover, Castilian regularly proved equally important, yet in different social situations, such as in neighbourhoods and while doing manual labour alongside Spaniards from the South and other immigrants. In contrast, the need to speak Wolof, increasingly the Senegalese lingua franca in politics, trade, and youth culture, demonstrated the limits of the multilingual ideology in Casamance.

The case studies have shown how the process of conviviality happens at the interplay of multiple dimensions of difference, which was reflected in both the configuration of the social fields, and the people's practices of polylanguaging and translation. Often strong supporters of multilingual repertoires, Casamançais normatively justified the equality and coexistence of multiple languages, styles, and registers in a local social field, yet at the same time situationally accepted, and creatively made use of, a lingua franca, as well as the appropriate styles and registers. Despite some like Aboubacar Diao who did not positively relate to multilingualism, many Casamançais valued (truncated) multilingualism since it facilitated the process of living with maintained differences. They saw themselves contributing to embracing linguistic and semiotic differences in translation, thus facilitating communication or, more generally, interaction. In practice, this often only involved features 'learned in passing', which is characteristic of phatic communion and thus temporary conviviality.

This observation is highly relevant for the question of multilingualism in relation to social hierarchies. As in Augustin Sambou's case, disempowered subject positions are situational. While he kept afloat in most social situations applying his wide repertoire, with the mechanic he failed at achieving both phatic communion and the desired economic outcome. Thus, while in the economic field multilingualism is a tactical choice to mediate unfavourable structural conditions and it may fail, in public spaces phatic communion can be created by the same people through the playful exchange of non-propositional language drawing on wide repertoires. In the latter case, conviviality, peaceful living with maintained difference, and the experience of relative situational equality are at stake, while in the former, truncated multilingualism resembles an economic investment.

Substantial differences and power disparities always entail the possibility of failure impeding the inherent translation process of polylanguaging. Cultural differences deriving from ethnic competition or competing language ideologies are closely related to, and mask questions of power. This was the case of the mechanic implicitly imposing the use of Wolof in Casamance, and the tactical use of Catalan by both Aboubacar and Idrissa. However, when phatic communion is established by creatively drawing from a wide repertoire and skillfully handling language ideologies, the situational 
salience of social hierarchies is temporarily reduced. For continued conviviality, Casamançais were adjusting to changing situations and contexts, which their truncated multilingualism reflected. While in this paper I have stressed the importance of language ideologies which emphasise underlying cultural, national, and ethnic differences, practising multilingualism and achieving phatic communion depends on competently addressing further social and economic differences. Variations in registers and style which Idrissa combined, for example, offered initial, but important insights into these dynamics.

Exploring multilingual practices and representations on a spectrum between coping tactic and phatic communion taking the crucial role of language ideologies into account has proven a productive way of understanding the polylanguaging of residents who live in diversified localities and remain different, yet often maintain conviviality. The process of conviviality spans both these aspects describing everdynamic and ever-fragile ways of living with difference.

\section{NOTES}

1 I wish to thank participants at the conference Language practices, migration and labour: ethnographing economies in urban diversities at the University of the Western Cape, Cape Town, 9-10/10/2012 for very helpful and constructive comments on earlier versions of this paper. Errors remain all mine.

2 I matched a sample of mainly male migrants and their relatives and friends. The fieldwork lasted for about 18 months between 2009 and 2010, equally split between Catalonia and Casamance. While I recorded 66 open-ended interviews, much of the presented material stems from informal conversations that are only documented in my fieldnotes, which explains the lack of direct quotations.

3 To also systematically take transit spaces as further influencing contexts into account could be promising, but lies beyond the scope of my material.

4 'Agreement to live together. National Agreement on Immigration.' (from Catalan).

5 All names have been changed. However, the first name shows the Christian or Muslim faith of an informant, while the last name indicates the real ethnic origins of the person. Where the latter is crucial for the analysis, the ethnicity is additionally mentioned separately.

6 Interviews of a Moroccan and subSaharan African published online support this fact (http://www.youtube. $\mathrm{com} /$ watch? $\mathrm{v}=\mathrm{RkA} 2 \mathrm{CJASaiY}$ [accessed 09/11/2012]).

7 Elsewhere, I more extensively discuss the aspects of cultural translation and the inherently comparative perspectives of migrants (cf. Heil 2013, 2014b).

8 Compañera/o is Castilian, company/a Catalan, and camarada exists in both.

9 It is likely that he consciously mentioned Jola well aware of the local rivalry of Jola and Mandinka speaking Casamançais in both Casamance and Catalonia.

\section{REFERENCES}

Agence Nationale de la Statistique et de la Démographie. 2008. Troisième recensement général de la population et de l'habitat (2002). Rapport national de présentation. Dakar: Agence Nationale de la Statistique et de la Démographie (ANSD).

Agence Nationale de la Statistique et de la Démographie. 2009. Recensement général de la population et de l'habitat 2002. Personal communication. Ziguinchor: Service Régional de la Statistique et de la Démographie de Ziguinchor.

Ajuntament de Mataró. 2010. Estudi de la Població. Mataró: Servei d'Estudis i Planificació. 
Blommaert, Jan, James Collins, and Stef Slembrouck. 2005. Spaces of Multilingualism. Language $\mathcal{E}^{\circ}$ Communication 25 (3): 197-216. doi: $<10.1016 /$ j.langcom.2005.05.002>.

Castells, Manuel. 2009. The Power of Identity. Malden: Wiley-Blackwell.

De Jong, Ferdinand, and Geneviève Gasser. 2005. Contested Casamance: Introduction. Canadian Journal of African Studies 39 (2): 213-29.

Diallo, Ibrahima. 2010. The Politics of National Languages in Postcolonial Senegal. Amherst: Cambria Press.

Díez Nicolás, Juan. 2002. Las dos caras de la inmigración. Madrid: Ministerio de Trabajo y Asuntos Sociales.

Dreyfus, Martine, and Caroline Juillard. 2005. Le plurilinguisme au Sénégal: Langues et identités en devenir.

Dictionnaires et langues. Paris: Karthala.

Evans, Martin. 2005. Insecurity or isolation? Natural resources and livelihoods in Lower Casamance. Canadian Journal of African Studies 39 (2): 282-312.

Foucher, Vincent. 2002. Cheated pilgrims: Education, migration and the birth of Casamançais nationalism (Senegal). Unpublished PhD dissertation. London: University of London.

Foucher, Vincent. 2003. Pas d'alternance en Casamance? Le nouveau pouvoir sénégalais face à la revendication séparatiste casamançaise. Politique Africaine 91: 101-19.

Foucher, Vincent. 2011. On the matter (and materiality) of the nation: Interpreting Casamance's unresolved separatist struggle. Studies in Ethnicity and Nationalism 11 (1): 82-103. doi: $<10.1111 /$ j.1754-9469.2011.01098.x >

Gal, Susan. 2013. Registers, schools and scales: Comments on language and identity in twenty-first century Catalonia. International Journal of Bilingual Education and Bilingualism 16 (2): 225-29. doi: $<10$. 1080/13670050.2012.720671>.

Estatut d'autonomia de Catalunya 2006. Generalitat de Catalunya. 2006. < http:// www.parlament.cat/porteso/estatut/ eac_ca_20061116.pdf>.
Generalitat de Catalunya. 2009. Un pacte per viure junts i juntes: Pacte nacional per a la immigració.

Generalitat de Catalunya. 2010a. Citizenship and Immigration Plan 2009-2010. Unpublished manuscript, last modified March 31, 2011. < http://www20.gencat. cat/docs/dasc/03Ambits\%20tematics/05 Immigracio/03Politiquesplansactuacio/ 03placiutadania09_012/01Presentacio/ pla_angles.pdf $>$.

Generalitat de Catalunya. 2010b. Pla de ciutadania i immigració 2009-2012. Unpublished manuscript, last modified March 31, 2011. < http://www20.gencat. cat/docs/dasc/03Ambits\%20tematics /05Immigracio/03Politiquesplansact uacio/03placiutadania09_012/01Pres entacio/pla_ciutadania_immigracio_ vcat_2010_06_03.pdf>.

Glick Schiller, Nina, Ayşe Çăglar, and Thaddeus C. Guldbrandsen. 2006. Beyond the ethnic lens: Locality, globality, and born-again incorporation. American Ethnologist 33 (4): 612-33.

Heil, Tilmann. 2012. Fragile convivialities: Everyday living together in two stateless but diverse regions, Catalonia and Casamance. MMG Working Papers 12-100. Unpublished manuscript, last modified April 04, 2013. < http://www.compas. ox.ac.uk/publications/working-papers/ wp-12-100/> .

Heil, Tilmann. 2013. Cohabitation and convivencia: Comparing conviviality in the Casamance and Catalonia. Unpublished PhD dissertation. Oxford: University of Oxford.

Heil, Tilmann. 2014a. Are neighbours alike? Practices of conviviality in Catalonia and Casamance. European Journal of Cultural Studies 17 (4): 452-70. doi: $<10.1177 / 1367549413510420>$.

Heil, Tilmann. 2014b. How and why does it matter to understand diverse urban engagements from the migrants' perspective? MMG Working Papers 14-03. Unpublished manuscript, last modified April 01, 2014. < http://www.mmg.mpg. de/publications/working-papers/2014/ wp-14-03/>. 
Instituto Nacional de Estadística. 2011. Revisión del padrón municipal 2010: Datos a nivel nacional, comunidad autónoma y provincia. <www.ine.es>.

Irvine, Judith T. 1989. When talk isn't cheap: Language and political economy. American Ethnologist 16 (2): 248-67.

Jørgensen, Jens N., Martha S. Karrebæk, Lian M. Madsen, and Janus S. Møller. 2011. Polylanguaging in Superdiversity. Diversities 13 (2): 23-38.

Juillard, Caroline. 1991. Le plurilinguisme au quotidien: Ziguinchor au Sénégal. Afrique Contemporaine 30 (158): 31-52.

Juillard, Caroline. 2005. Plurilinguisme et variation sociolinguistique à Ziguinchor (Sénégal). VALS/ASLA 82: 117-32.

Juillard, Caroline, Marie-Louise Moreau, Pape Alioune Ndao, and Ndiassé Thiam. 1994. Leur wolof dit-il qui ils sont? La perception des appartenances régionales et ethniques au travers du wolof urbain parlé par les adolescents. Langage et Société 68 (1): 35-62.

Lambert, Michael. 1998. Violence and the war of words: Ethnicity v. nationalism in the Casamance. Africa 68 (4): 585-602.

Malinowski, Bronislaw. (1923) 1994. The problem of meaning in primitive languages. In Maybin, Janet (ed). Language and Literacy in Social Practice: A Reader. Clevedon: Multilingual Matters. $1-10$.

Marut, Jean-Claude. 2010. Le conflit de Casamance: Ce que disent les armes. Hommes et sociétés. Paris: Karthala.

May, Stephen. 2012. Language and Minority Rights: Ethnicity, Nationalism and the Politics of Language. New York: Routledge.

McLaughlin, Fiona. 2008. The ascent of Wolof as an urban vernacular and national lingua franca in Senegal. In Cecile B. Vigouroux and Salikoko
S. Mufwene (eds). Globalization and

Language Vitality: Perspectives from Africa. London: Continuum. 142-70.

Pujolar, Joan. 2009. Immigration in Catalonia: Marking territory through language. In James Collins, Stef Slembrouck, and Mike Baynham (eds). Globalization and Language in Contact: Scale, Migration, and Communicative Practices. London: Continuum. 85-105.

Pujolar, Joan, and Isaac Gonzàlez. 2013. Linguistic 'mudes' and the de-ethnicization of language choice in Catalonia. International Journal of Bilingual Education and Bilingualism 16 (2): 138-52. doi: $<10.1080 / 13670050.2012 .720664>$.

Swigart, Leigh. 2000. The limits of legitimacy: Language ideology and shift in contemporary Senegal. Journal of Linguistic Anthropology 10 (1): 90-130. doi: <10.1525/jlin.2000.10.1.90>.

Wimmer, Andreas, and Nina Glick Schiller. 2002. Methodological nationalism and beyond: Nation-state building, migration and the social sciences. Global Networks 2 (4): 301-34. doi: $<10.1111 / 1471-0374.00043>$.

Wimmer, Andreas, and Nina Glick Schiller. 2003. Methodological nationalism, the social sciences, and the study of migration: An essay in historical epistemology. International Migration Review 37 (3): 576-610.

Woolard, Kathryn A., and Susan E. Frekko. 2013. Catalan in the twentyfirst century: Romantic publics and cosmopolitan communities. International Journal of Bilingual Education and Bilingualism 16 (2): 129-37. doi: $<10.1080 / 13670050.2012 .720663>$. 